\title{
Pengembangan Badan Usaha Milik Desa (BUMDes) di Jawa Timur
}

\section{Development of Village-Owned Enterprises (BUMDes) in East Java}

\author{
Septi Ariadi* \\ Departemen Sosiologi, Fakultas Ilmu Sosial dan Ilmu Politik Universitas Airlangga \\ Surabaya, 60286, Jawa Timur, Indonesia \\ E-mail corresponding author: septi.ariadi@ fisip.unair.ac.id
}

\author{
Sudarso \\ Departemen Sosiologi, Fakultas Ilmu Sosial dan Ilmu Politik Universitas Airlangga \\ Surabaya, 60286, Jawa Timur, Indonesia \\ E-mail: sudarso@fisip.unair.ac.id
}

\begin{abstract}
Abstrak
Gagasan untuk mengembangkan BUM-Des, boleh dikata masih merupakan wacana yang relatif baru. Sebagai sebuah wilayah administratif pemerintahan yang paling bawah, desa di era otonomi daerah seperti sekarang ini, dituntut untuk mampu mengembangkan sikap mandiri di bidang ekonomi, termasuk membiayai sebagian dari kegiatan pembangunan di wilayahnya. Tujuan dari penulisan ini adalah untuk mengkaji gambaran tentang mekanisme pengelolaan badan usaha milik desa (BUM-Des) yang ada di berbagai desa di Provinsi Jawa Timur. Dengan menggunakan metode penelitian kualitatif, secara purposive, kegiatan pengkajian ini dilaksanakan di 5 kabupaten dan 25 desa di Provinsi Jawa Timur. Hasil dari penelitian ini didapati bahwa BUM-Des bukanlah lembaga yang dibentuk dan tumbuh dari bawah (bottom up), melainkan lebih merupakan lembaga bentukan dari atas (top down) yang diinisiasi dari prakarsa Negara. Besar modal awal pembentukan BUM-Des, sebagian besar $(60 \%)$ di atas 25 juta rupiah, bahkan 24\% BUM-Des yang ada didirikan dengan modal awal 100 juta lebih. Sedangkan faktor yang dinilai sangat menghambat perkembangan BUM-Des, menurut 41,8\% masyarakat desa adalah modal yang terbatas.
\end{abstract}

Kata Kunci: bum-des, desa, otonomi daerah; ekonomi, pembangunan; masyarakat desa

\begin{abstract}
Idea to develop BUM-Des, can be said is still a relatively new discourse. As an administrative area of the lower government, the village in the era of regional autonomy, as today, is required to be able to develop an independent attitude in the economic field, including financing some of its development activities in the region. The purpose of this writing is to examine the overview of the management mechanisms of the village-owned enterprises (BUM-Des) in various villages in the province of East Java. By using qualitative research method, in purposive, this assessment activity is conducted in 5 districts and 25 villages in East Java province. The result of this study was found that BUM-Des was not an institution formed and grown from below (bottom up), but rather a top down institution initiated from the state's initiative. Most (60\%) Over 25 million rupiahs, even 24\% of the existing BUM-Des was established with an initial capital of 100 million. While the factors assessed greatly hindered the development of BUM-Des, according to $41.8 \%$ of the village community is a limited capital.
\end{abstract}

Keywords: BUM-Des, village, regional autonomy; economics, development; village community

\section{Pendahuluan}

Sejak pemerintah mengeluarkan UU No. 22 Tahun 1999 tentang Pemerintah Daerah dan UU No. 25 Tahun 1999 tentang Perimbangan Keuangan Pusat dan Daerah, maka desakan agar segera diberlakukan otonomi dan desentralisasi yang benar- benar nyata terasa makin menguat - termasuk sampai ke tingkat desa (Maruto \& Mariyanti, 2001; Lapera, 2000; Widarta, 2001). Sebagai sebuah wilayah administratif pemerintahan yang paling bawah, desa di era otonomi daerah seperti sekarang ini, bukan hanya dituntut mampu merencanakan program pembangunan secara bottom-up dan mengakomodsi partisipasi masyarakatnya sendiri, tetapi di saat yang sama desa juga dituntut untuk mampu mengembangkan sikap mandiri di bidang ekonomi, termasuk membiayai sebagian dari kegiatan pembangunan di wilayahnya (Suhartono, 2001; Tjokrowinoto, 1992). Mungkinkah desa-desa 
itu --tak terkecuali desa-desa di Provinsi Jawa Timur-- mampu berotonomi dalam artian yang sebenarnya? Di tengah keterbatasan sumber-sumber dana yang dimiliki saat ini, mungkinkah desa mencari dan mengembangkan sumber- sumber dana alternatif seperti layaknya badan usaha milik desa (BUM-Des) (Seyadi, 2003).

Sebelum desa-desa di Indonesia memperoleh kucuran dana desa yang mencapai ratusan juta atau bahkan satu milyar lebih, kemungkinan untuk menghela akselerasi pembangunan di perdesaan mungkin sulit dilakukan.Tetapi, setelah pemerintah mencanangkan arti penting pembangunan desa dan kemudian didukung dengan kebijakan pengucuran dana desa, maka peluang desa untuk mengembangkan program-program yang kontekstual, termasuk mengembangkan BUM-Des harus diakui menjadi lebih terbuka (Maryunani, 2008).

Secara konseptual, kita tentu telah memahami bahwa pengertian otonomi daerah sekurang-kurangnya mengandung dua unsur utama. Pertama, otonomi mesti menjalankan prinsip- prinsip desentralisasi pemerintahan. Dalam hal ini, otonomi harus menjamin desentralisasi politik seluas-luasnya, adil, demokratis, pluralistik, dan memberdayakan pemerintah daerah, bahkan sampai ke tingkat desa. Kedua, otonomi harus menjamin prinsip desentralisasi fiskal. Artinya daerah harus diberi kewenangan mengelola sumber daya alam serta menentukan insentif fiskal dan alokasi dana bagi pembangunan. Jadi, kebijakan yang menempatkan desa sebagai sentral pembangunan dan program pengucuran dana pembangunan ke berbagai desa, sesungguhnya adalah implementasi dari penerapan kebijakan otonomi daerah (Mahardika, 2001).

Cuma yang menjadi masalah: berbeda dengan wilayah kabupaten-kota yang memang dalam UU di atas telah diberi otoritas untuk mengatur jalannya pemerintahan dan pengalokasian dana pembangunan sesuai kebutuhan setempat, di tingkat desa kebijakan otonomi yang dijalankan boleh dikata masih setengah hati. Secara politis, seluruh desa yang ada sekarang ini memang telah diberi keleluasaan politik untuk merancang kebutuhan dan program-program pembangunan di wilayahnya lewat wakilwakil mereka yang tergabung dalam BPD (Badan Perwakilan Desa), dan tidak lagi sekadar menerima program - nasi bungkus dari pusat yang serba seragam dan sentralistik. Namun demikian, untuk mengembangkan sumber-sumber pemasukan ekonomi yang cukup, acap terjadi desa-desa yang ada masih kesulitan. Jangankan untuk membiayai secara mandiri kebutuhan program pembangunan di wilayah desanya, untuk memenuhi kebutuhan rutin kesejahteraan pamong desanya saja sering terjadi desa masih kesulitan akibat tidak dimilikinya harta atau kas desa yang cukup (Kuncahyo, 2000).

Di beberapa wilayah, mungkin ada desa yang memiliki tanah bengkok atau tanah kas desa yang cukup luas sehingga dapat mencukupi kebutuhan hidup pamong desa. Tetapi, tidak jarang di daerah yang lain pamong desa harus hidup serba pas-pasan, dan bahkan kekurangan karena mereka tidak memperoleh tanah bengkok yang cukup dan layak untuk dikembangkan sebagai sebuah sumber penghasilan. Di desa- desa yang tandus, misalnya, tanah bengkok yang ada seringkali tidak produktif, sehingga diberi berapa pun luasnya tidak akan banyak berarti karena memang tidak menghasilkan apa-apa. Hasil studi yang dilakukan Suyanto \& Mochammad (2001) di sejumlah desa di Jawa Timur menemukan adanya indikasi bahwa tanah bengkok yang semula hanya diperuntukkan untuk kesejahteraan pamong desa, kini dituntut agar sebagian dibagi kepada anggota BPD. Mungkinkah dapat mencukupi?

Untuk menambal kebutuhan desa dan meningkatkan sumber-sumber penghasilan desa yang potensial, salah satu peluang yang dapat diraih adalah dengan mengandalkan pada badan usaha milik desa. Dalam penjelasan UU No. 22 Tahun 1999 Pasal 108 disebutkan bahwa desa dapat memiliki badan usaha sesuai dengan peraturan- perundang-undangan yang berlaku. Artinya, desa dapat melakukan perbuatan hukum, baik hukum publik maupun perdata, memiliki kekayaan, harta benda dan pembangunan serta dapat dituntut dan menuntut di pengadilan. Untuk itu, Kepala Desa dengan persetujuan Badan Perwakilan Desa (BPD) mempunyai wewenang untuk melakukan perbuatan hukum dan mengadakan perjanjian yang saling menguntungkan dengan pihak lain - sepanjang isi perjanjian itu memang secara langsung maupun tidak langsung bermanfaat bagi kesejahteraan masyarakat desa secara keseluruhan. 
Secara substansial, pemberian kewenangan kepada berbagai desa untuk mencari sumber-sumber pemasukan atau dana pembangunan, sebetulnya bukanlah hal yang baru. Sejak jaman penjajahan, telah dicatat ahli-ahli sejarah bahwa desa-desa yang ada, khususnya di Pulau Jawa telah diberi otonomi untuk mengatur dirinya sendiri, termasuk mengatur harta-benda desa. Selain hak milik atas tanah, desa biasanya juga memiliki apa yang disebut kas desa dan harta desa. Seperti diatur dalam Inlandsche Gemeente Ordonnantie, bahwa rumah tangga desa tidak mungkin diselenggarakan apabila tidak ada biaya untuk mendukung penyelenggaraan pemerintahan desa. Ketika kebutuhan desa masih kecil- kecilan, memang kadang-kadang Kepala Desa dan pegawai desa yang mampu masih bisa menutupinya dengan uang pribadi. Tetapi, ketika kebutuhan pembangunan desa makin besar dan tidak bisa dicukupi semata hanya mengandalkan dana pribadi pamong desa, maka makin mendesak kebutuhan untuk memiliki kas desa.

Menurut catatan sejarah, sejak jaman penjajahan Belanda, tepatnya tahun 1900-an awal, telah banyak usaha dilakukan desa untuk memperbesar penghasilan kas desa. Ada desa yang menanam pohon randu di pinggir jalan atau di tegalan yang hasil keuntungannya kemudian dimasukkan ke kas desa. Ada pula desa yang berbudi-daya ikan di rawa-rawan atau di kali desa, kemudian jika sudah besar, ikan itu dijual untuk selanjutnya keuntungan yang diperoleh dimasukkan ke dalam kas desa. Pada jaman dulu, yang termasuk harta desa adalah harta pasar, harta pengairan, harta perbaikan jenis rojokoyo, dan harta jaminan (Kartohadokoesoemo, 1984).

Untuk konteks saat ini, sudah barang tentu jenis usaha apa yang layak dikembangkan masing-masing desa tidak lagi sama dengan cerita di masa silam. Bersamaan dengan terjadinya proses modernisasi dan komersialisasi di pedesaan, bentuk-bentuk badan usaha yang dikembangkan desa telah berkembang makin beragam, mulai dari kegiatan penyewaan lahan, koperasi simpan-pinjam, persewaan huller dan peralatan tani lainnya, sampai ke pembukaan usaha komersial penggilingan gabah, dan lain-lain. Pendek kata, peluang usaha di masing- masing desa memang tidak sama, dan keberanian Kepala Desa untuk memilih usaha mana yang dinilai menguntungkan juga ikut menentukan jenis usaha apa yang kemudian dikembangkan desa-desa yang bersangkutan.

Menurut aturan yang berlaku, apa pun jenis usaha yang dikembangkan desa tentu itu semua harus dimanfaatkan sebesar-besarnya untuk kepentingan masyarakat desa itu sendiri. Jadi, seperti layaknya badan usaha milik publik, maka aparat desa juga bertanggungjawab untuk secara transparan melaporkan berbagai keuntungan yang diperoleh dari kegiatan usaha desa yang mereka kembangkan, termasuk melaporkan pengalokasian dana keuntungan itu untuk apa saja, dan kegiatan pembangunan apa di wilayahnya masing-masing.

Tetapi, seperti biasa terjadi: antara aturan yang telah ditetapkan dengan kenyataan di lapangan terkadang tidak selalu berjalan beriringan. Kendati dalam aturan yang berlaku jelas disebutkan kewajiban aparat desa dan apa fungsi pengembangan badan usaha milik desa, tetapi dalam praktek ditengarai terkadang masih terjadi berbagai penyimpangan. Dikhawatirkan hasil keuntungan dari pengembangan badan usaha milik desa terkadang masih masuk dan dimanfaatkan untuk kepentingan pribadi orang per orang atau kelompok-kelompok tertentu yang kurang mencerminkan kepentingan masyarakat desa secara keseluruhan. Akibat mekanisme pengelolaan yang belum jelas, dan kontrol publik yang kurang karena ketidaktahuan masyarakat desa itu sendiri, maka penyimpangan dan kebocoran pun terkadang tidak terhindarkan terjadi.

Di Kota/Kabupaten di Provinsi Jawa Timur, gagasan untuk mengembangkan BUM-Des, boleh dikata masih merupakan wacana yang relatif baru. Belum semua desa yang memiliki dan benar-benar telah berhasil mengembangkan BUM-Des yang benar-benar bermanfaat bagi kepentingan masyarakat desa secara keseluruhan. Dalam rangka merumuskan format pengelolaan badan usaha milik desa di Provinsi Jawa Timur yang lebih transparan dan dapat dipertanggungjawabkan, oleh sebab itu perlu dilakukan sebuah kegiatan pengkajian yang benar-benar intensif di lapangan. Kegiatan sebagaimana diusulkan penting dilakukan, karena di era otonomi ini, persoalan yang dihadapi desa makin lama makin pelik dan menuntut adanya transparansi dan partisipasi masyarakat yang benar-benar nyata. 
Secara rinci, beberapa permasalahan yang dikaji dalam kegiatan ini adalah: (1) Bagaimana gambaran tentang mekanisme pengelolaan badan usaha milik desa (BUM-Des) yang ada di berbagai desa di Provinsi Jawa Timur? Sejauhmana mekanisme pengelolaan yang dijalankan telah menjamin prinsipprinsip akuntabilitas dan transparansi? (2) Kendala-kendala apa sajakah yang menghambat upaya pengembangan badan usaha milik desa di Propinsi Jawa Timur? Termasuk di sini, pembenahanpembenahan apa yang perlu dilakukan untuk lebih menjamin efektivitas dan efisiensi pelayanan BUM-Des? (3) Faktor-faktor apa sajakah yang menyebabkan BUMDes di Provinsi Jawa Timur berhasil memperlihatkan kinerja dan perkembangan yang bermanfaat bagi masyarakat dan pemerintahan desa? (4) Sejauhmana keberadaan badan usaha milik desa di Provinsi Jawa Timur telah terbukti memberikan manfaat bagi upaya peningkatan kesejahteraan masyarakat desa dan jalannya penyelenggaraan pemerintahan desa?

\section{Metode Penelitian}

Studi ini mengkaji tentang eksistensi badan usaha milik desa, juga sekaligus merumuskan strategi pengembangan Badan Usaha Milik Desa (BUM-Des) di Kabupaten Provinsi Jawa Timur yang mendukung upaya peningkatan kesejahteraan masyarakat desa serta proses penyelenggaraan pemerintahan desa dan kebijakan otonomi pemerintahan desa. Secara purposive, kegiatan pengkajian ini dilaksanakan di 5 kabupaten dan 25 desa di Provinsi Jawa Timur.

Tabel 1.

Lokasi penelitian

\begin{tabular}{|c|c|c|c|}
\hline Kabupaten & Kecamatan & Desa & Jumlah responden \\
\hline \multirow{5}{*}{$\begin{array}{l}\text { Kabupaten } \\
\text { Malang }\end{array}$} & Kecamatan Bantur & Desa Rejoyoso & 20 \\
\hline & Kecamatan Gondanglegi & Desa Putukrejo & 20 \\
\hline & Kecamatan Kepanjen & Desa Kemiri & 20 \\
\hline & Kecamatan Wajak & Desa Kidangbang & 20 \\
\hline & Kecamatan Bululawang & Desa Kuwolu & 20 \\
\hline \multirow{5}{*}{$\begin{array}{l}\text { Kabupaten } \\
\text { Pamekasan }\end{array}$} & Kecamatan Pegantenan & Desa Pegantenan & 20 \\
\hline & Kecamatan Palengaan & Desa Potoan Daya & 20 \\
\hline & Kecamatan Pademawu & Desa Murtajih & 20 \\
\hline & Kecamatan Galis & Desa Polagan & 20 \\
\hline & Kecamatan Pamekasan & Desa Teja Timur & 20 \\
\hline \multirow{5}{*}{$\begin{array}{l}\text { Kabupaten } \\
\text { Blitar }\end{array}$} & Kecamatan Sanan Kulon & Desa Sumberejo & 20 \\
\hline & Kecamatan Kademangan & Desa Plosorejo & 20 \\
\hline & Kecamatan Wonotirto & Desa Kaligrenjeng & 20 \\
\hline & Kecamatan Bakung & Desa Kedungbanteng & 20 \\
\hline & Kecamatan Kanigoro & Desa Minggirsari & 20 \\
\hline \multirow{5}{*}{$\begin{array}{l}\text { Kabupaten } \\
\text { Nganjuk }\end{array}$} & Kecamatan Sukomoro & Desa Pehserut & 20 \\
\hline & Kecamatan Bagor & Desa Balongrejo & 20 \\
\hline & Kecamatan Nganjuk & Desa Kedungdowo & 20 \\
\hline & Kecamatan Rejoso & Desa Talangrejo & 20 \\
\hline & Kecamatan Gondang & Desa Campur & 20 \\
\hline \multirow{5}{*}{$\begin{array}{l}\text { Kabupaten } \\
\text { Bojonegoro }\end{array}$} & Kecamatan Balen & Desa Pilanggede & 20 \\
\hline & Kecamatan Kepohbaru & Desa Sugihwaras & 20 \\
\hline & Kecamatan Baureno & Desa Ngemplak & 20 \\
\hline & Kecamatan Kanor & Desa Kedungprimpen & 20 \\
\hline & Kecamatan Sugihwaras & Desa Bareng & 20 \\
\hline
\end{tabular}


Untuk memperoleh masukan dan data yang akurat, dalam kegiatan ini bahan-bahan yang dibutuhkan dikumpulkan melalui tiga cara, yakni: Pertama, mengkaji dan menganalisis data sekunder dari berbagai studi yang telah dilakukan sebelumnya mengenai pembangunan desa dan badan usaha milik desa. Review terhadap berbagai hasil studi yang kepustakaan yang telah ada ini, penting dilakukan untuk dasar pertama memetakan kondisi masyarakat desa dan pasang-surut perkembangannya badan usaha milik desa yang ada di Provinsi Jawa Timur.

Kedua, melakukan penggalian data primer ke lapangan, mewawancarai aparat desa, sesepuh desa, tokoh informal, aktivis lokal, dan sebagainya untuk memperoleh gambaran yang valid dan akurat mengenai prospek dan kondisi badan usaha milik desa. Selain itu, untuk mengetahui manfaat BUMDes bagi upaya mensejahterakan kondisi sosial-ekonomi masyarakat, dalam penelitian ini juga diwawancarai 500 masyarakat desa sebagai responden penelitian.

Tabel 1 menunjukkan lokasi studi ditetapkan di 5 kabupaten, yaitu: di Kabupaten Malang, Kabupaten Pamekasan, Kabupaten Blitar, Kabupaten Bojonegoro, Kabupaten Nganjuk. Di masing-masing kabupaten, menurut rencana akan diteliti 5 BUMDes dan 100 masyarakat desa, sehingga total jumlah yang diwawancarai 500 responden.

Ketiga, melakukan wawancara mendalam kepada Kepala Desa, ulama, masyarakat, aparat Pemda setempat - khususnya dinas atau sektor terkait yang bertanggungjawab dalam pembinaan badan usaha milik desa.

Seluruh data yang berhasil dikumpulkan, setelah melalui proses editing dan pengklasifikasian kemudian dianalisis dan diinterpretasi. Secara keseluruhan, laporan yang disusun lebih banyak berupa esai-esai yang lebih menekankan kedalaman analisis, dan bukan pada pengukuran-pengukuran kekuatan hubungan antar variabel. Di akhir laporan, selain ditampilkan kesimpulan hasil kajian yang telah dilakukan, juga dikemukakan sejumlah rekomendasi penting dan strategis tentang arah pengembangan badan usaha milik desa dalam mendukung upaya peningkatan kesejahteraan masyarakat desa, proses penyelenggaraan pemerintahan desa, pembangunan dan otonomi daerah di Provinsi Jawa Timur.

\section{Hasil dan Pembahasan}

Dalam kegiatan pembangunan desa perubahan tentu tidak hanya diharapkan terjadi pada aspek fisik dan kelembagaan saja, tetapi juga perubahan pada taraf kehidupan dan derajat partisipasi masyarakat secara keseluruhan dalam menyelenggarakan pembangunan di wilayahnya (Beckhard, 2000; Condrey, 1998). Pembangunan dan pemberdayaan masyarakat desa ibaratnya adalah dua sisi mata uang yang tak bisa dipisahkan. Suatu pembangunan desa dikatakan berhasil tidak hanya apabila pembangunan itu berhasil mengurangi jumlah orang miskin atau berhasil menyediakan jalan mulus, membangun gedung-gedung sekolah, jembatan yang kokoh atau membangun berbagai prasarana ekonomi. Namun, juga harus diukur dengan sejauh mana pembangunan desa yang dikembangkan dapat menimbulkan kemauan dan kemampuan dari masyarakat desa untuk maju dan mandiri. Dalam arti kemauan dan kemampuan masyarakat desa itu sendiri untuk menciptakan pembangunan dan melestarikan serta mengembangkan hasil-hasil pembangunan - baik yang berasal dari usaha mereka sendiri maupun yang berasal dari prakarsa yang datang dari luar masyarakat itu.

Selama proses transformasi yang dijalankan dalam satu-dua dekade terakhir, pembangunan ekonomi di satu sisi harus diakui memang telah menghasilkan pertumbuhan yang tinggi. Tetapi, harus diakui bahwa kemajuan di bidang ekonomi yang termasuk spektakuler itu ternyata belum sepenuhnya dapat mengatasi permasalahan kemiskinan dan kesenjangan antar daerah. Di berbagai daerah, ada sejumlah dilema yang harus dihadapi pemerintah dalam melaksanakan dan merencanakan program pembangunan. Sejumlah dilema pembangunan yang dihadapi bukan hanya berkaitan dengan masalah pelayanan dasar yang belum merata dan masalah kualitas sumber daya manusia yang realatif rendah, tetapi juga berkaitan dengan pilihan orientasi pembangunan yang keliru. Akibat orientasi 
pembangunan yang cenderung mementingkan pusat-pusat pertumbuhan dan kota besar, sering terjadi wilayah pedesaan menjadi tertinggal atau terpaksa ditinggalkan dalam kegiatan pembangunan karena selain dipandang kurang produktif, juga karena secara geografis maupun politis jauh dari pusat (Sanford, 2003; Goldthorpe, 1992). Sekadar contoh: pembangunan Jembatan Suramadu, misalnya, di satu sisi memang merupakan kemajuan karena membantu memperlancar mobilitas sosial warga masyarakat Madura. Tetapi, di sisi yang lain kita tidak menutup mata pembangunan pasca pembangunan Jembatan Suramadu arus masyarakat Madura bepergian dan membelanjakan uang di luara daerah juga meningkat pesat --yang ujung-ujungnya membuat perputaran jumlah uang cash di Madura menurun drastis.

Sudah barang tentu ada banyak faktor yang menyebabkan kenapa pembangunan yang dikembangkan pemerintah justru menimbulkan polariasasi dan proses marginalisasi. Tetapi, yang jelas salah satu faktor yang menjadi penyebab berbagai program pembangunan kurang memberikan hasil yang maksimal adalah bersumber pada masalah manajemen pembangunan yang kurang berjalan dengan baik, terutama di bidang perencanaan, pelaksanaan dan pengawasan program (Wren, 1994; Esman, 1991; Beckhard, 2000). Menurut Robert Chambers (1987), kenyataan kemiskinan dan kesenjangan masih merebak di berbagai negara sedang berkembang adalah karena para perencana pembangunan seringkali hanya bertindak seperti "turis pembangunan" dan bertindak sebagai "orang luar" yang bersikap sok tahu, sehingga dalam banyak hal kurang empatif terhadap situasi yang sebenarnya terjadi di wilayah. Di berbagai negara, banyak bukti menunjukkan bahwa para perencana pembangunan cenderung dipenuhi dengan prasangka atau syakwasangka dan mereka terlalu percaya pada angkaangka statistik yang sesungguhnya kurang dapat dipercaya.

Di berbagai negara sedang berkembang, dalam tahap penyusunan program maupun pelaksanaan program seringkali terjadi bias - menurut Bryant dan Louise (1989) salah satu penyebabnya adalah karena tidak didukung oleh kemampuan sumber daya manusia, khususnya aparat birokrasi yang memadai. Di samping itu, acap terjadi program pembangunan tidak tepat pada sasaran karena perencanaan hanya menjadi semacam mode, formalitas, dan bahkan ritualitas, serta sedikit atau malah tak ada kaitan dan akibatnya sama sekali terhadap keputusan sehari-hari. Rencana-rencana yang disusun dengan susah-payah dan ideal hanyalah macan di atas kertas. Selain itu, penyusunan kegiatan operasionalpun seringkali tidak secara serius menterjemahkan apa sebenarnya tujuan dasar dari pembangunan yang direncanakan.

Per definisi, perencanaan sesungguhnya adalah suatu penanganan masalah secara holistik. Perencanaan sering berarti penetapan tujuan dan prioritas serta serangkaian kegiatan untuk mencapainya. Perencanaan tidak semata-mata merupakan persoalan instrumentasi sasaran-sasaran secara efisien, lebih dari itu perencanaan pembangunan adalah suatu proses yang mungkin mengantar masyarakat menemukan masa depannya (Bryant \& Louise, 1989).

Di tengah keterbatasan sumber dana yang dimliki desa, salah satu peluang yang potensial dikembangkan masing-masing desa di Provinsi Jawa Timur sesungguhnya adalah dengan mendorong pendirian dan pengembangan BUMDes yang mandiri dan keberlanjutan. Studi sebagaimana dilaporkan, pada batas-batas tertentu telah berhasil mengidentifikasi berbagai kelebihan yang dimiliki BUMDes, kendala-kendala apa saja yang menghambat untuk dapat segera diselesaikan di masa depan, dan ke arah mana sebetulnya BUMDes ini hendak dikembangkan.

Sebagai lembaga sosial-ekonomi bentukan dari atas yang sifatnya top- down, harus diakui tidak banyak desa yang benar-benar siap dengan program pendirian dan pengembangan BUMDes. Namun demikian, mengingat partisipasi dan kebutuhan masyarakat lokal yang meningkat, mau tidak mau desa harus mulai menjajagi dan mengembangkan BUMDes yang kontekstual. Dengan memanfaatkan sense of belonging masyarakat desa itu sendiri, diharapkan ke depan perkembangan BUMDes dapat makin marak, dan mampu menjalankan perannya untuk membantu peningkatan taraf hidup dan perkembangan usaha masyarakat desa. Perkembangan BUMDes ke depan diharapkan tidak sekadar mengedepankan efisiensi pengelolaan (Gajduschek, 2003), tetapi yang lebih penting adalah 
mengedepankan efektivitas pengelolaan, yakni melayani kebutuhan masyarakat miskin sekaligus mempercepat upaya penanggulangan kemiskinan di Provinsi Jawa Timur.

Dari hasil penelusuran data ke lapangan yang telah dilakukan, terdapat beberapa temuan pokok dari kegiatan kajian yang dilakukan. Sebagai lembaga sosial-ekonomi yang dimaksudkan untuk memfasilitasi kelancaran jalannya pemerintahan desa dan membantu memenuhi kebutuhan masyarakat desa, proses awal kelahiran BUMDes umumnya adalah aparatur pemerintahan desa (69\%) dan Kepala Desa (25\%). Artinya, BUMDes bukanlah lembaga yang dibentuk dan tumbuh dari bawah (bottom up), melainkan lebih merupakan lembaga bentukan dari atas (top down) yang diinisiasi dari prakarsa negara.

Besar modal awal pembentukan BUMDes, sebagian besar (60\%) di atas 25 juta rupiah, bahkan $24 \%$ BUMDes yang ada didirikan dengan modal awal 100 juta lebih. Sebanyak 18\% BUMDes didirikan dengan modal sekitar 75-100 juta. Namun demikian, cukup banyak (40\%) BUMDes yang didirikan dengan modal di bawah 25 juta rupiah. Setelah sekian lama beroperasi, modal yang dikelola BUMDes rata-rata meningkat (78\%), bahkan $13 \%$ meningkat tajam. Tidak ada satupun BUMDes yang modalnya menurun. Sebagian besar BUMDes, rata-rata kenaikan modal yang dikelola meningkat 2-3 kali lipat dari modal awal. Hal ini sedikit-banyak berkaitan dengan jumlah usaha yang dikembangkan BUMDes. Sebagian besar BUMDes mengelola lebih dari 1 usaha, bahkan cukup banyak yang lebih dari 3 jenis usaha $(46 \%)$.

Dalam pandangan para pengurus, perkembangan BUMDes selama ini umumnya meningkat. Sebagian besar pengurus bahkan sudah memiliki rencana untuk mengembangkan usaha baru di tahun depan, dan memastikan merealisasikannya. Meski saat ini sebagian besar BUMDes (67\%) mengembangkan usaha simpan-pinjam, tetapi ke depan akan dikembangkan berbagai jenis usaha lain yang menguntungkan. Sebagian besar laporan keuangan BUMDes selalu (78\%) dilaporkan secara terbuka. Sebagai lembaga yang dimaksudkan untuk membantu kelancaran penyelenggaraan pemerintahan desa, meski relatif kecil, yakni hanya di bawah 2,5 juta rupiah, tetapi kehadiran BUMDes telah memberikan sumbangan bagi PAD desa dan juga bagi perkembangan perekonomian desa, terutama membantu menyediakan kebutuhan modal usaha bagi masyarakat desa.

Faktor yang menghambat upaya pengembangan BUMDes, menurut sebagian besar pengurus adalah keterbatasan modal yang dimiliki, yang menyebabkan BUMDes tidak leluasa untuk meningkatkan daya jangkau layanan kepada masyarakat yang lebih luas. Untuk itu, ke depan bantuan yang dibutuhkan untuk mendukung pengembangan BUMDes adalah kucuran tambahan modal yang dapat dimanfaatkan untuk meningkatkan daya layanan dan modal untuk membuka jenis usaha baru yang menguntungkan.

Tingkat pendidikan nasabah BUMDes, tersebar dari jenjang pendidikan rendah hingga tinggi. Namun demikian, sebagian besar responden mengaku berpendidikan relatif rendah. Sebanyak 31,2\% responden berpendidikan setingkat $\mathrm{SD}$, dan $31,2 \%$ responden berpendidikan setingkat SMP. Hanya $3 \%$ responden yang berpendidikan PT/Akademi, dan 34,6\% responden berpendidikan setara SMA. Sementara itu, pekerjaan yang ditekuni responden, sebagian besar $(41,4 \%)$ di sektor pertanian, yakni sebagai petani pemilik atau buruh tani. Sebanyak $27,6 \%$ responden mengaku berkerja di sektor informal, $15,4 \%$ di sektor industri kecil, $15 \%$ sebagai pedagang tradisional, dan $0,6 \%$ sebagai buruh pabrik. Seperti kebanyakan masyarakat desa yang lain, sebagian besar responden umumnya menekuni pekerjaan yang tidak termasuk sektor perekonomian firma. Sebagian besar responden adalah pekerja di sektor yang biasanya ditekuni masyarakat desa dari golongan menengah ke bawah.

Meskipun tidak semua nasabah BUMDes termasuk miskin, tetapi sebagian besar responden $(63,6 \%)$ responden termasuk keluarga yang secara ekonomi nyaris miskin (near poor). Dari 500 keluarga yang diteliti, 20,8\% termasuk miskin, dan bahkan ada 3,8\% yang termasuk sangat miskin. Hanya 11,8\% yang termasuk keluarga sejahtera. Dari 500 masyarakat desa yang diwawancarai, studi ini menemukan bahwa sebagian besar $(75,4 \%)$ umumnya baru tidak lebih dari tahun menjadi nasabah BUMDes. 
Mereka adalah penduduk desa yang termasuk pionir memanfaatkan tawaran pinjaman bantuan dana dari BUMDes. Hanya 6,2\% yang termasuk nasabah kawakan BUMDes di desanya. Sebanyak 3,8\% sudah sekitar 6-8 tahun menjadi nasabah BUMDes, dan sebanyak 14,6\% mengaku sudah 3-5 tahun menjadi nasabah BUMDes.

Sebagian besar masyarakat desa mengaku mengetahui keberadaan BUMDes di desanya dari aparat desa $(60,2 \%)$ dan $16,2 \%$ dari pengurus BUMDes itu sendiri. Dari 500 masyarakat desa yang diwawancarai, hanya $11 \%$ yang mengaku mengetahui BUMDes atas dasar pengetahuannya sendiri -bukan dari orang lain. Sementara itu, sebanyak 5,8\% mengaku mengetahui soal BUMDes dari keluarga, dan sebanyak 6,8\% mengaku mengetahui dari informasi tetangga. Dari 500 masyarakat desa yang diwawancarai, hanya sebagian kecil yang mengaku pernah memperoleh pinjaman dari BUMDes hingga 3 kali. Dalam setahun terakhir, hanya 15,8\% yang pernah memperoleh pinjaman hingga 2 kali dari BUMDes. Sebagian besar $(83,4 \%)$ mengaku dalam setahun terakhir baru sekali saja pernah memperoleh pinjaman dari BUMDes.

Di berbagai desa yang menjadi lokasi studi, penelitian ini menemukan sebagian besar $(84,2 \%)$ usaha yang dikembangkan BUMDes adalah simpan-pinjam (banking). Jenis usaha ini harus diakui paling praktis dan mudah dikembangkan, karena pangsa pasarnya jelas, dan pengelolaannya pun mudah. Untuk jenis usaha yang lain, seperti jasa perantara $(5,2 \%)$, usaha bersama $(12,4 \%)$, persewaan $(10,4 \%)$, perdagangan $(15,6 \%)$ dan pelayanan sosial bagi warga desa $(17 \%)$ tidak atau belum banyak dikembangkan BUMDes. Dengan modal yang terbatas, harus diakui tidak terlalu banyak pilihan usaha yang bisa dikembangkan BUMDes, sehingga ketika harus menyusun skala prioritas, maka usaha simpan-pinjam menjadi pilihan utama dari berbagai BUMDes yang ada.

Dibandingkan jenis usaha lain, seperti perdagangan, usaha bersama, jasa perantara, persewaan atau pelayanan sosial, hampir semua $(92,4 \%)$ sepakat bahwa usaha BUMDes yang paling dibutuhkan masyarakat adalah simpan-pinjam. Kelebihan BUMDes dibandingkan lembaga sosial- ekonomi lain, terutama pada suku bunga pinjaman yang dinilai tidak membebani nasabah. Sebanyak 49,4\% menyatakan suku bunga pinjaman BUMDes jauh lebih baik daripada lembaga perkreditan lain. Selain itu, dari aspek persyaratan $(44,8 \%)$, kecepatan pelayanan $(42 \%)$, pembayaran cicilan $(41,4 \%)$ dan kemudahan birokrasi pengurusannya $(40,2 \%)$, sebagian besar masyarakat desa menyatakan jauh lebih baik BUMDes.

Dibandingkan Kopwan, Koppontren dan BPR, meminjam ke BUMDes menurut sebagian besar masyarakat desa jauh lebih baik, dan bahkan bila dibandingkan dengan rentenir atau bank thithil, sebanyak 49\% menyatakan BUMDes jauh lebih baik, dan 45,6\% menyatakan BUMDes masih lebih baik. Artinya, meskipun kehadiran rentenir di berbagai perdesaan acapkali menawarkan kemudahan dan kecepatan layanan, tetapi karena suku bunga pinjaman rentenir disadari cenderung tinggi, maka sebagian besar masyarakat desa menyatakan lebih baik jika meminjam ke BUMDes.

Studi ini menemukan, kecenderungan masyarakat di desa memanfaatkan fasilitas yang ditawarkan BUMDes tidak banyak yang berasal dari inisiatif masyarakat desa sendiri $(18,4 \%)$. Sebagian besar masyarakat desa mengaku inisiatif memanfaatkan jasa layanan BUMDes, termasuk tawaran bantuan modal usaha umumnya karena ditawari pengurus BUMDes $(67,2 \%)$. Dari 500 nasabah BUMDes yang diwawancarai, 96,8\% mengaku selama ini memang mereka tidak pernah ditolak tatkala mereka mengajukan pinjaman kepada BUMDes. Tetapi, mereka juga mengakui bahwa prakarsa meminjam ke BUMDes sebetulnya lebih banyak karena ditawari pengurus dan itu pun biasanya dibatasi hanya pada 1 kesempatan saja karena ketersediaan modal BUMDes yang terbatas.

Terlepas, dari siapa inisiatif meminjam dan berapa kali mereka meminjam ke BUMDes, menurut sebagian besar masyarakat desa, kehadiran BUMDes bermanfaat $(52,6 \%)$, dan bahkan $46 \%$ menyatakan sangat bermanfaat. Walaupun dengan dukungan dana yang masih terbatas, tetapi sebagian besar kondisi BUMDes yang diteliti umumnya berkembang (71,2\%), dan bahkan $18 \%$ responden menyatakan sangat berkembang. Hanya 10,4\% masyarakat desa yang menyatakan kondisi BUMDes di desanya stagnan, dan hanya 0,4\% menyatakan menurun. Dari 500 masyarakat desa yang diteliti, 
$71,4 \%$ optimis prospek perkembangan BUMDes ke depan akan cerah. Sebanyak $28 \%$ menyatakan biasa-biasa saja, dan hanya 0,6\% yang pesimis karena merasa perkembangan BUMDes ke depan suram.

Faktor yang dinilai sangat menghambat perkembangan BUMDes, menurut $41,8 \%$ masyarakat desa adalah modal yang terbatas. Sebagai lembaga sosial-ekonomi baru, tentu BUMDes membutuhkan dukungan dana yang besar agar mereka dapat menjangkau masyarakat yang lebih luas. Tetapi, sayangnya, di berbagai desa, modal yang dimiliki BUMDes diakui masyarakat masih terbatas, sehingga kemungkinan untuk mengembangkan daya layanan juga terkendala.

\section{Strategi pengembangan BUMDes}

Atas dasar temuan data yang diperoleh dari hasil kajian lapangan di sejumlah desa lokasi penelitian sebagaimana ditunjukkan Tabel 2, maka beberapa rekomendasi yang perlu diperhatikan jika sebuah wilayah ingin mengembangkan BUM-Des di Provinsi Jawa Timur adalah sebagai berikut:

Pertama, untuk mendorong perkembangan BUMDes agar lebih maju dan memberikan sumbangan yang lebih signifikan bagi kepentingan masyarakat dan pemerintahan desa, ada baiknya jika BUMDes yang ada tidak sekadar menjalankan usaha yang sifatnya konvensional, seperti usaha simpan-pinjam. Di masing-masing desa, akan lebih baik jika BUMDes yang ada juga melakukan diversifikasi usaha sesuai dengan potensi keunggulan lokal dan kemampuan yang dimiliki pengurus BUMDes di masingmasing desa yang ada. Dengan kata lain, pilihan usaha apa yang nantinya dikembangkan masingmasing BUMDes, sudah tentu harus menakar potensi yang dimiliki desa, baik potensi sumber daya alam maupun potensi SDM yang ada, sehingga usaha apapun yang dikembangkan nanti akan dapat berkelanjutan.

Kedua, dalam rangka meningkatkan pasokan modal dan memperluas jangkauan pelayanan yang diberikan kepada penduduk desa dalam skala yang lebih luas, maka BUM-Des mau tidak mau harus mulai merintis kerjasama dengan pihak ketiga, baik itu dengan dinas pemerintah maupun berbagai lembaga donor yang bersedia memberikan pinjaman lunak dengan bunga yang tidak terlalu memberatkan. Sebagai lembaga ekonomi dan lembaga perkreditan desa yang juga memiliki muatan dan tujuan sosial, jelas sulit berharap BUM-Des bisa dikelola sepenuhnya berorientasi profit (keuntungan). Untuk itu, kalau pun ada kerjasama dengan pihak ketiga swasta, hendaknya menjajagi kemungkinan memanfaatkan dana dari program CD (Community Development) atau dana Program CSR dari perusahaan/BUMN yang selama ini masih belum termanfaatkan secara maksimal, bahkan cenderung terabaikan. Dukungan dana dari pihak luar ini dibutuhkan, untuk mempercepat perkembangan BUMDes, sehingga akan memungkinkan jangkauan layanan menjadi lebih luas dan peran BUMDes sebagai lembaga penggerak aktivitas perekonomian desa menjadi kesampaian.

Untuk menjajagi kemungkinan dan realisasi kerjasama BUM-Des dengan BUMN/perusahaan yang ada di wilayah Provinsi Jawa Timur maupun wilayah lain, inisiatif dari pihak Pemerintah Provinsi Jawa Timur — dalam hal ini Gubernur dan pimpinan DPRD Provinsi Jawa Timur - sangat dibutuhkan dalam rangka menandatangi MOU, sekaligus sebagai garansi sosial bahwa dana bantuan yang disalurkan dari Program CD atau Program CSR dari BUMN/perusahaan benar-benar bisa dimanfaatkan sebesar-besarnya untuk kesejahteraan masyarakat dan desa. Selama ini, sudah menjadi rahasia umum bahwa jumlah dana Program CSR dari perusahaan/BUMN umumnya belum semua tersalurkan dengan baik. Dengan jaminan dan kerja keras Pemerintah Provinsi Jawa Timur diharapkan berbagai BUMDes yang ada di berbagai kota/kabupaten di Jawa Timur dapat mengakses dan memanfaatkan dana dari Program CSR untuk kepentingan pembangunan dan pemberdayaan masyarakat desa. 
Tabel 2.

Program pengembangan bumdes di Provinsi Jawa Timur

\begin{tabular}{|c|c|c|c|}
\hline Kebijakan & $\begin{array}{c}\text { Program } \\
\text { pengembangan }\end{array}$ & Tujuan & Leading sector \\
\hline $\begin{array}{l}\text { Diversifikasi } \\
\text { usaha }\end{array}$ & $\begin{array}{l}\text { Pemberian } \\
\text { bantuan modal } \\
\text { usaha untuk } \\
\text { pengembangan } \\
\text { usaha } \\
\text { baru BUMDes }\end{array}$ & $\begin{array}{l}\text { Mendorong } \\
\text { perkembangan } \\
\text { usaha BUMDes } \\
\text { yang lebih } \\
\text { beraneka-ragam }\end{array}$ & $\begin{array}{l}\text { Dinas Koperasi } \\
\text { dan UMKM }\end{array}$ \\
\hline $\begin{array}{l}\text { Memperbesar } \\
\text { modal }\end{array}$ & $\begin{array}{l}\text { Kerjasama } \\
\text { dengan } \\
\text { Program CSR } \\
\text { BUMN/BUMD }\end{array}$ & $\begin{array}{l}\text { Mencari sumber-sumber } \\
\text { permodalan dan } \\
\text { memperluas daya } \\
\text { jangkau layanan } \\
\text { BUMDes }\end{array}$ & $\begin{array}{l}\text { Dinas Koperasi } \\
\text { dan UMKM }\end{array}$ \\
\hline $\begin{array}{l}\text { Transparansi } \\
\text { BUMDes }\end{array}$ & $\begin{array}{l}\text { Pelibatan OJK } \\
\text { dalam pemeriksaan } \\
\text { dan peran serta } \\
\text { masyarakat desa } \\
\text { dalam } \\
\text { pengawasan } \\
\text { kinerja } \\
\text { BUMDes } \\
\end{array}$ & $\begin{array}{l}\text { Mendorong pengelolaan } \\
\text { BUMDes yang lebih } \\
\text { terbuka dan bisa } \\
\text { dikontrol masyarakat }\end{array}$ & $\begin{array}{l}\text { Bagian } \\
\text { Pemerintahan }\end{array}$ \\
\hline $\begin{array}{l}\text { Kelangsungan } \\
\text { perkembangan } \\
\text { BUMDes }\end{array}$ & $\begin{array}{l}\text { Pengembangan } \\
\text { usaha berbasis } \\
\text { potensi lokal }\end{array}$ & $\begin{array}{l}\text { Menjamin } \\
\text { keberlangsungan } \\
\text { usaha } \\
\text { BUMDes ke depan }\end{array}$ & $\begin{array}{l}\text { Dinas Koperasi } \\
\text { dan UMKM }\end{array}$ \\
\hline $\begin{array}{l}\text { Pengelolaan dan } \\
\text { pengurus } \\
\text { BUMDes }\end{array}$ & $\begin{array}{l}\text { Pelatihan } \\
\text { manajemen dan } \\
\text { pendampingan } \\
\text { pengurus } \\
\text { BUMDes }\end{array}$ & $\begin{array}{l}\text { Meningkatkan kualitas } \\
\text { SDM BUMDes dan } \\
\text { mencegah } \\
\text { kemungkinan } \\
\text { terjadinya bias } \\
\text { kepentingan }\end{array}$ & $\begin{array}{l}\text { Dinas Tenaga } \\
\text { Kerja }\end{array}$ \\
\hline $\begin{array}{l}\text { BUMDes yang } \\
\text { UMKMable. }\end{array}$ & $\begin{array}{l}\text { Prioritas layanan } \\
\text { bagi pelaku } \\
\text { UMKM }\end{array}$ & $\begin{array}{l}\text { Mendorong } \\
\text { pengembangan } \\
\text { usaha simpan-pinjam } \\
\text { BUMDes yang lebih } \\
\text { ramah kepada } \\
\text { pelaku } \\
\text { UMKM }\end{array}$ & $\begin{array}{l}\text { Dinas Koperasi } \\
\text { dan UMKM }\end{array}$ \\
\hline $\begin{array}{l}\text { Pengembangan } \\
\text { usaha BUMDes } \\
\text { yang memiliki } \\
\text { ersatz (fungsi } \\
\text { kedua sebuah } \\
\text { komoditi) yang } \\
\text { mampu mengikat } \\
\text { loyalitas } \\
\text { konsumen }\end{array}$ & $\begin{array}{l}\text { Pelatihan bagi } \\
\text { pengurus BUMDes }\end{array}$ & $\begin{array}{l}\text { Mendorong } \\
\text { pengembangan usaha } \\
\text { BUMDes yang mampu } \\
\text { menggaet selera } \\
\text { pasar/konsumen }\end{array}$ & $\begin{array}{l}\text { Disperindag dan } \\
\text { Perguruan Tinggi }\end{array}$ \\
\hline
\end{tabular}

Sumber: Data primer

Ketiga, untuk mendukung pengembangan BUMDes di berbagai desa di Provinsi Jawa Timur, selain mengandalkan pada dukungan dari program dana desa yang digelontorkan pemerintah pusat, ada baiknya jika pemerintah daerah mengalokasikan dana subsidi hibah sebagai tambahan modal bagi BUMDes di berbagai desa untuk mengembangkan kegiatannya. Sudah barang tentu, untuk bisa memberikan subsidi yang merata bagi semua desa, pihak eksekutif perlu meyakinkan arti penting 
BUM-Des ini kepada DPRD setempat. Seperti sudah dipaparkan dalam laporan ini, bahwa BUM-Des di berbagai desa yang dikelola dengan baik, bukan saja terbukti mampu membantu perkembangan kegiatan produktif masyarakat, tetapi juga bisa memberikan sumbangan yang cukup bermakna bagi penyelenggaraan pemerintahan desa. BUM-Des yang makin besar dan dikelola secara transparan, tidak mustahil akan bisa menjadikan masing-masing desa memiliki dana abadi yang bermanfaat bagi pembangunan desa itu sendiri ke depan.

Dalam hal ini, untuk menjamin agar pengelolaan BUM-Des tetap transparan dan bisa dipertanggungjawabkan, maka selain laporan keuangan harus ditata dengan baik dan setiap saat bisa dikontrol oleh BPD, pengawas kecamatan, maupun Kepala Desa, yang tak kalah penting adalah bagaimana mempertanggungjawabkan kinerja BUMDes secara transparan kepada publik berupa pengumuman tertulis yang dipasang di kantor desa - sehingga siapa pun bisa membacanya. Sebagai lembaga milik bersama, sejak awal mesti disadari bahwa BUM-Des adalah milik bersama masyarakat desa. Dan, dengan mempromosikan BUMDes kepada publik, maka salah satu efek samping yang diharapkan bisa dirasakan manfaatnya oleh masyarakat desa makin kenal kepada BUM-Des, sehingga di saat yang sama ruang gerak bang thithil atau lembaga perkreditan informal lain yang biasanya menetapkan bunga yang mencekik leher bisa dieliminasi. Satu hal yang semestinya disadari bahwa sebuah lembaga akan bisa tetap eksis, selain terbukti fungsional, juga lembaga tersebut harus mampu menumbuhkan sense of bellongging (rasa memiliki) dari masyarakat.

Keempat, bagi desa-desa yang baru mencoba mengembangkan BUM- Des atau masih pada taraf awal penjajagan pengembangan BUMDes, seyogianya pada awal kegiatan pengembangan BUMDes membatasi pada kegiatan tertentu yang dikuasai pengurus BUMDes, semisal usaha simpan-pinjam karena selain secara administratif mudah dipantau, juga karena lebih menjamin kemungkinan dilakukan kelancaran perputaran uang. Sudah barang tentu, di balik tawaran bunga pinjaman yang harus relatif lebih rendah daripada pasar, BUM-Des juga perlu memastikan bahwa nasabah harus bersedia menyerahkan agunan agar bisa dieliminasi kemungkinan terjadinya tunggakan dari nasabah. Jika dalam 2-3 tahun modal yang dimiliki BUM-Des makin besar, maka keinginan untuk menjangkau dan meningkatkan pelayanan kepada penduduk desa yang miskin - yang tidak memiliki surat atau barang berharga untuk diagunkan bisa saja dilakukan sepanjang ada garansi dari tokoh masyarakat setempat terhadap reputasi si peminjam.

Sebagai lembaga perkreditan yang memiliki fungsi sosial, keberadaan BUM-Des seyogianya mampu menarik simpati masyarakat dengan cara mampu menawarkan besar suku bunga pinjaman yang kompetitif di pasaran. Kehadiran BUM-Des, di saat yang sama juga harus mampu mengeliminasi ruang gerak berbagai lembaga kredit informal, seperti bang thithil, pengijon, dan sejenisnya. Hanya sayang, akibat keterbatasan modal yang dimiliki, wilayah jangkauan BUM-Des rata-rata masih sangat terbatas.

Kelima, untuk menjaga agar tidak terjadi bias kepentingan dari aparat desa setempat dalam pengelolaan dan upaya pengembangan BUMDes, maka siapa saja yang terlibat sebagai pihak pengelola BUM-Des dianjurkan sebaiknya dari pihak di luar pamong desa dan BPD. Namun demikian, siapa pun yang ditunjuk menjadi pengurus BUM-Des seyogianya terlebih dahulu mendapat persetujuan dari Kepala Desa dan BPD. Penunjukkan pihak-pihak di luar aparatur pemerintahan desa ini penting dilakukan, terutama untuk menghindari konflik kepentingan dan kemungkinan melakukan pengawasan yang lebih transparan dan objektif.

Keenam, belajar dari pengalaman dan hasil studi yang telah dilakukan, pihak yang menjadi pengelola BUMDes seyogianya didahulukan dan diserahkan pada orang- orang yang memang memiliki rekam jejak reputatif dan dikenal baik oleh masyarakat lokal. Tokoh-tokoh perempuan atau aktivitis perempuan ada baiknya lebih keprioritaskan terlibat dalam pengelolaan BUMDes, karena hubungan atau jejaring sosial yang mereka miliki umumnya luas dan memperoleh kepercayaan publik yang luas. 
Penelitian terdahulu telah memperlihatkan bahwa BUM-Des yang pengurusnya adalah penduduk setempat khususnya perempuan, ternyata mampu mengkombinasikan dengan baik sistem pengelolaan administrasi yang profesional-rasional dengan pendekatan personal kepada anggota atau masyarakat desa sebagai kelompok sasaran program. Sekali pun merupakan lembaga yang sederhana dan dikelola hanya oleh warga masyarakat setempat, BUM-Des ternyata mampu mengembangkan mekanisme kontrol melalui sanksi yang bersifat informal, tetapi seringkali justru terbukti lebih efektif. Kelangsungan dan perkembangan BUM-Des sendiri sudah barang tentu sangat tergantung pada adanya rasa memiliki bersama (sense of bellongging) di antara anggota dan warga masyarakat.

Ketujuh, bagi pengurus BUMDes seyogianya menyadari paradigma baru pengelolaan lembaga sosialekonomi dan cara pandang pengelola BUMDes agar benar-benar pro kepada usaha mikro dan kecil. Artinya, ke depan arah pengembangan BUMDes di Provinsi Jawa Timur yang memiliki usaha simpanpinjam seyogianya tidak terjebak pada efisiensi penyaluran kredit kepada pelaku UMKM secara umum, tetapi untuk jangka pendek seyogianya lebih fokus pada pelaku usaha mikro dan kecil terlebih dahulu. Seperti diketahui, yang namanya UMKM pada dasarnya memiliki karakteristik usaha yang bermacam-macam. Oleh karenanya diperlukan skema pembiayaan yang bermacam-macam pula sesuai dengan karakter usaha yang mereka tekuni. Sebagai contoh, karakter usaha kerajinan berbeda dengan trading, pertanian, peternakan, industri pengolahan dan jenis usaha lainnya.

Masing-masing jenis usaha membutuhkan skema pembiayaan yang mestinya tidak seragam. Kalangan pengelola BUMDes oleh karena itu dituntut untuk lebih kreatif mengembangkan berbagai model pembiayaan yang dapat diakses dengan mudah oleh UMKM. Ke depan, para pengelola BUMDes dituntut berpikir kreatif dengan keterbatasan aturan yang membelitnya untuk memproduksi berbagai skim pembiayaan yang kapabel bagi UMKM. Bukan sebaliknya, UMKM dituntut untuk memenuhi syarat-syarat teknis yang kadang sulit dijangkau oleh sebagian besar pelaku UMKM. Singkat kata, ke depan seyogianya bukan pelaku UMKM yang dituntut untuk bankable, tetapi justru para pengelola BUMDes yang ditunntut agar UMKMable.

Harus disadari bahwa tidak berhasilnya target pengucuran kredit ke UMKM selama ini lebih dikarenakan masih sulitnya UMKM memenuhi persyaratan bank teknis (UMKM dianggap belum bankable). Anggapan ini harus dirubah menjadi sebenarnya lembaga sosial-ekonomi yang ada --tak terkecuali BUMDes-- yang belum UMKMable. Perubahan sudut pandang ini mensyaratkan bahwa selain UMKMnya dituntut untuk berubah lebih tertib dan baik, para pengelola BUMDes juga harus melakukan perubahan. Tuntutan agar UMKM menjadi bankable seharusnya bukan sebagai jurang yang terjal bagi UMKM yang benar-benar memerlukan uluran tangan perbankan untuk meningkatkan kinerja usahanya. Sebaliknya, para pengelola BUMdes juga dituntut untuk berempati dan jeli dalam menangkap peluang bisnis yang dikelola oleh para pelaku UMKM.

Kedelapan, dalam rangka mendorong transparansi dan evaluasi kinerja BUMDes, ada baiknya jika ke depan juga dilihatkan peran OJK dalam pemeriksaan BUMDes. Pelibatan peran OJK ini penting dilakukan untuk menjamin transparansi dan akuntabilitas kinerja BUMDes di masyarakat.

Kesembilan, sebagai lembaga sosial-ekonomi yang melayani kebutuhan masyarakat, terutama kebutuhan modal usaha, ada baiknya jika BUMDes tidak hanya menyalurkan bantuan dalam bentuk pinjaman modal usaha, tetapi juga sekaligus melakukan pendampingan ke masyarakat untuk memastikan perkembangan usaha yang ditekuni masyarakat dapat berjalan dengan optimal.

Kesepuluh, agar usaha yang dikembangkan BUMDes ke depan dapat diterima pasar dan menguntungkan, salah satu prasyarat yang dibutuhkan adalah pengetahuan para pengelola BUMDes tentang strategi pemasaran yang efektif. Di era perkembangan masyarakat postmodern, perlu disadari bahwa perilaku konsumen --tak terkecuali masyarakat desa-- telah bergeser tidak hanya menimbang fungsi intrinsik sebuah komoditi yang dibeli, tetapi juga mempertimbangan fungsi kedua komoditi itu atau yang disebut TW Adorno (seorang teoritisi Mazhab Frankfurt) sebagai ersatz. Ersatz adalah fungsi kedua dari sebuah komoditi yang acapkali justru menjadi pertimbangan utama yang mendorong seseorang membeli dan mengkonsumsi sebuah produk atau komoditi. Usaha apapun yang 
dikembangkan pengelola BUMDes, oleh sebab itu penting untuk diketahui apa yang menjadi ersatznya, untuk kemudian dapat ditawarkan dan mengikat loyalitas konsumen.

\section{Simpulan}

Di tengah keterbatasan sumber dana yang dimliki desa, salah satu peluang yang potensial dikembangkan masing-masing desa di Provinsi Jawa Timur sesungguhnya adalah dengan mendorong pendirian dan pengembangan BUMDes yang mandiri dan keberlanjutan. Sebagai lembaga sosialekonomi bentukan dari atas yang sifatnya top- down, harus diakui tidak banyak desa yang benar-benar siap dengan program pendirian dan pengembangan BUMDes. Namun demikian, mengingat partisipasi dan kebutuhan masyarakat lokal yang meningkat, mau tidak mau desa harus mulai menjajagi dan mengembangkan BUMDes yang kontekstual.

Berbagai upaya yang bisa dilakukan agar BUMDes dapat berjalan secara optimal adalah melakukan diversifikasi usaha sesuai dengan potensi keunggulan lokal; merintis kerjasama dengan pihak ketiga, baik dengan dinas pemerintah maupun lembaga donor; pemerintah daerah mengalokasikan dana subsidi hibah sebagai tambahan modal; membatasi pada kegiatan tertentu yang dikuasai pengurus BUMDes; menjaga agar tidak terjadi bias kepentingan dari aparat desa setempat dalam pengelolaan BUMDes; pengelola BUMDes diserahkan pada orang yang memiliki rekam jejak reputatif dan dikenal baik oleh masyarakat lokal; pengurus BUMDes seyogianya menyadari paradigma pengelolaan lembaga sosial-ekonomi dengan pro kepada usaha mikro dan kecil; pelibatan peran OJK dalam pemeriksaan BUMDes; melakukan pendampingan untuk memastikan perkembangan usaha yang ditekuni masyarakat; pengetahuan para pengelola BUMDes tentang strategi pemasaran yang efektif.

\section{Daftar Pustaka}

Beckhard R (2000) What is Organization Development? dalam French et al. Organization Development and Transformation: Managing Effective Change. Boston: Irwin MCGraw-Hill.

Bryant C \& Louise GW (1989) Manajemen Pembangunan Untuk Negara Berkembang. Jakarta: LP3ES.

Chambers R (1987) Pembangunan Desa, Mulai Dari Belakang. Jakarta: LP3ES.

Condrey SE (1998) Handbook of Human Resource Managementin Government. San Fransisco: Jossey-Bass Publishers.

Esman MJ (1991) Management Demensions of Development Perspectives and Strategies. Oakwood, Conecticut: Kumarian Press.

Gajduschek G (2003) Bureaucracy: Is it efficient? Is it not? Is that the question? Uncertainty reduction: An ignored element of bureaucratic rationality. Administration and Society 34 (6):700-723.

Goldthorpe JE (1992) Sosiologi Dunia Ketiga, Kesenjangan dan Pembangunan. Jakarta: Gramedia.

Kartohadikoesoemo S (1984) Desa. Jakarta: PN Balai Pustaka.

Kuncahyo E (2000) Pembangunan Desa Dengan Memanfaatkan Potensi Tanah Kas Desa. Makalah.

LAPERA (2000) Otonomi Versi Negara. Yogyakarta: LAPERA Pustaka Utama.

Maruto A \& Maryanti C (2001) Jaman Daulat Rakyat: Dari Otonomi Daerah ke Demokratisasi. Yogyakarta: LAPERA Pustaka Utama.

Mahardika T (2001) Strategi Tiga Kaki: dari Pintu Otonomi Daerah Mencapai Keadilan Sosial. Yogyakarta: LAPERA Pustaka Utama.

Maryunani (2008) Pembangunan Bumdes dan Pemerdayaan Pemerintah Desa. Bandung: CV Pustaka Setia.

Sanford JR (2003) Exploring the structuration of technology within human service organizations. Administration \& Society 34 (6):605-631.

Seyadi (2003) Bumdes sebagai Alternatif Lembaga Keuangan Desa. Yogyakarta: UPP STM YKPN.

Suyanto B \& Mochammad J (2001) Budaya dan Pembangunan. Surabaya: Lutfansyah.

Suhartono dkk (2001) Politik Lokal: Parlemen Desa, Awal Kemerdekaan Sampai Jaman Otonomi Daerah. Yogyakarta: LAPERA Pustaka Utama. 
Tjokrowinoto M (1992) Birokrasi Pembangunan Masyarakat, dalam Effendi, S., et al., Membangun Martabat Manusia: Peranan Ilmu-ilmu Sosial dalam Pembangunan. Yogyakarta: Gajah Mada University Press.

Widarta I (2001) Cara Mudah memahami Otonomi Daerah. Yogyakarta: LAPERA.

Pustaka Utama.Wren DA (1994) The Evolution of Management Thought $\left(4^{\text {th }}\right.$ ed.). New York: John Wiley \& Sons, Inc. 